
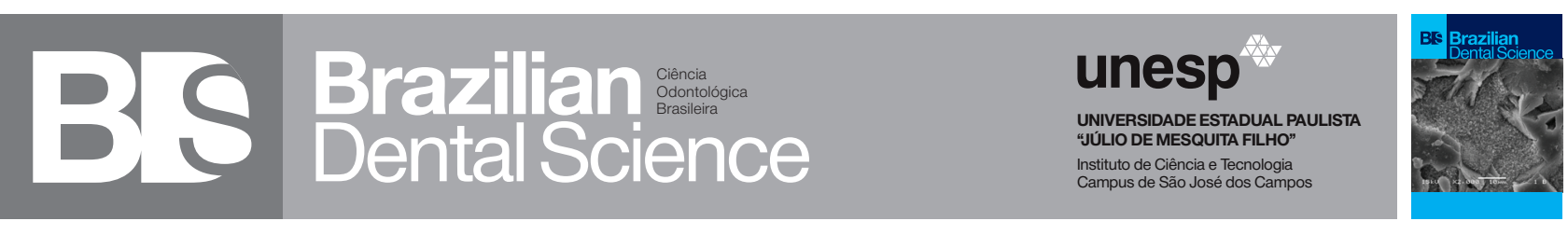

\title{
Parental perceptions of oral health-related quality of life of brazilian children andadolescents with autism spectrum disorder
}

Percepção dos responsáveis da qualidade de vida relacionada à saúde oral de crianças e adolescentes brasileiros com transtorno do espectro do autista

Viviane CANCIO ${ }^{1}$, Khawana FAKER ${ }^{1}$, Mônica Almeida TOSTES ${ }^{1}$

1 - Department of Pediatric Dentistry - School of Dentistry - Fluminense Federal University - Niterói - RJ - Brazil.

\section{ABSTRACT}

Objective: This paper aimed to assess the oral healthrelated quality of life (OHRQoL) of children and adolescents with autism spectrum disorder (ASD) using the parental/caregiver perceptions questionnaire (PCPQ). Material and methods: Children aged 2 to 14 years, enrolled in the ACOLHER/PNE project at the Fluminense Federal University, RJ, Brazil, were assessed. The main independent variable was dental caries experience, diagnosed according to the World Health Organization (WHO) criteria. The variable was categorized as caries-free when $\mathrm{dmft} / \mathrm{DMFT}=$ 0 and caries experience when $\mathrm{dmft} / \mathrm{DMFT} \geq 1$. Caregiver schooling, age, sex, and socioeconomic factors (Brazilian minimum wage - BMW) were the other independent variables. Quality of life (QoL) was measured using PCPQ subscales and total score. Mann-Whitney U, Kruskal-Wallis, and multivariate Poisson regression correlation analysis were performed. Results: The median age of patients was $8(\mathrm{SD}=3.76)$. The study group consisted of 57 (76.0\%) males and 18 (24.0\%) females. Fifty parents (66.7\%) have more than eight years of education and 35 (46.7\%) earn less than 2 BWM. The impact values were significantly higher in male individuals in the oral symptoms (OS) domain and in individuals without caries experience in the social well-being (SW) domain ( $\mathrm{p}<0.05)$. Conclusions: these results seem to suggest that individuals with ADS without caries experience in permanent dentitions in the SW domain and males in the OS domain had a higher impact quality of life.

\section{KEYWORDS}

Quality of life; Oral health; Dental caries; Autistic disorder; Perception.

\section{RESUMO}

Objetivo: Este artigo teve como objetivo avaliar a qualidade de vida relacionada à saúde bucal (OHRQoL) de crianças e adolescentes com transtorno do espectro do autista (TEA), utilizando o questionário de percepção dos pais / cuidadores (PCPQ). Material e métodos: Foram avaliadas crianças de 2 a 14 anos matriculadas no projeto ACOLHER / PNE da Universidade Federal Fluminense, RJ, Brasil. A principal variável independente foi a experiência de cárie dentária, diagnosticada de acordo com os critérios da Organização Mundial da Saúde (OMS). A variável foi categorizada como livre de cárie quando dmft / DMFT $=0$ e experiência de cárie quando dmft / CPOD $\geq 1$. Escolaridade do cuidador, idade, sexo e fatores socioeconômicos (salário mínimo brasileiro - BMW) foram as outras variáveis independentes. A qualidade de vida (QV) foi mensurada usando as subescalas PCPQ e o escore total. Foram realizadas análises de correlação de regressão de Mann-Whitney U, KruskalWallis e multivariada de Poisson. Resultados: A idade média dos pacientes foi de 8 anos ( $\mathrm{DP}=3,76)$. O grupo de estudo foi composto por $57(76,0 \%)$ homens e 18 (24,0\%) mulheres. Cinquenta pais $(66,7 \%)$ têm mais de oito anos de escolaridade e 35 (46,7\%) ganham menos de 2 MBM. Os valores de impacto foram significativamente maiores em indivíduos do sexo masculino no domínio de sintomas orais (OS) e em indivíduos sem experiência de cárie no domínio do bem-estar social (SW) (p <0,05). Conclusões: esses resultados parecem sugerir que indivíduos com ADS sem experiência de cárie em dentição permanente no domínio SW e homens no domínio OS tiveram maior impacto na qualidade de vida.

\section{PALAVRAS-CHAVE}

Qualidade de vida; Saúde bucal; Cárie dentária; Desordem do espectro autista; Percepção. 


\section{INTRODUCTION}

A utism spectrum disorder (ASD) is a lifelong disorder characterized by impairments in social and communicative functioning and by the presence of restricted interests/repetitive behaviors $[1,2]$. It has been estimated that 1 in 68 (14.6 per 1,000) school-aged children has ASD in the USA [1]. However, according to the Census conducted by the Brazilian Institute of Geography and Statistics (IBGE), Brazil has 45 million people with disabilities, but subjects with ASD have not been estimated separately [3].

The health status of ASD individuals in Brazil is poorly investigated. In other countries, previous research has mainly focused on oral health and family socioeconomic status $[4,5]$. ASD is a widely recognized disease that can have varying impacts on people and on their well-being and quality of life [4-10]. Investigations have shown that health problems such as dental caries can affect individuals functionally, psychologically, and socially, causing pain and discomfort in children and adolescents with special healthcare needs [4-10]. In individuals with ASD, oral healthrelated quality of life (OHRQoL) could have a different impact on families when compared to healthy children [4,5]. The impact of autism on families is very large from the emotional, social, and economic points of view [4,5]. Pani et al. [4] suggest that childhood autism results in reduced OHRQoL for the affected child and significantly poorer Parental-Caregiver Perceptions Questionnaire (PCPQ) scores than those of parents without an autistic child.

The PCPQ was constructed to measure the perception of parents/caregivers regarding the impact of oral health on the quality of life of their children [11]. This instrument has been cross-culturally adapted and validated in a number of countries, including Brazil
[12]. According to Richa et al. [5], functional limitation was significantly higher among children with autism compared to children without autism. However, there is little information regarding the effects of OHRQoL of autistic children on the quality of life of their families. Oral examination of autistic children is very difficult, which justifies the limited literature available and shows the importance of this work. Therefore, the aim of this study was to use parental perceptions to assess the OHRQoL of children with ASD.

\section{MATERIAL AND METHODS}

\section{Ethical approval}

Written informed consent was obtained from the parents or legal guardians of all participants and the study procedures were clearly explained to the parents/guardians and participants before their inclusion. This crosssectional study was conducted according to Brazilian Resolution no. 466 (2012) principles for medical research involving human subjects. The study protocol was approved by the Human Research Ethics Committee of the Fluminense Federal University (process $\mathrm{n}^{\circ}$. 439.086/2013).

\section{Study population}

The cross-sectional study was carried out between January and December 2017. The sample size was calculated based on the total prevalence of ASD, which is $1 \%$ for the Brazilian population [3], using a $95 \%$ confidence interval and a sampling error of $5 \%$. The sample should have included 50 parents of children and adolescents (another 20 subjects were included). The total sample was 70 subjects aged 2 to 14 years enrolled in the ACOLHER-PNE project of the Dental School of the Fluminense Federal University, in the city of Niterói, Rio de Janeiro, Brazil. Subjects who were not able to cooperate due 
to their medical conditions and those children whose parents refused to give consent were not included in the study $\left(\mathrm{n}^{\circ}\right.$ subjects were excluded). Subjects whose legal guardians consented to their participation and those who gave assent to study participation were eligible to participate in the study. The diagnosis of ADS was based on records made available by the medical informed made available by those responsible for.

\section{Calibration of examiners}

The research team was made up of two dentists (VC-examiner 1 and KF-examiner 2) who had participated in a training and calibration exercise for caries status 2). The calibration exercise consisted of theoretical and clinical steps. The theoretical step involved a discussion on the criteria for the diagnosis of decayed, missing and filled teeth index (dmft for primary teeth/DMFT for permanent teeth). These steps were reviewed and discussed by the examiners and by an experienced dentist (gold standard). The clinical step was conducted with 40 subjects aged 8 and 9 years on two occasions with a two-week interval between examinations. These subjects were not included in the main sample. The intra-examiner and interexaminer Kappa coefficients were 0.89 and 0.96 , respectively.

\section{Data collection}

The parents self-completed the PCPQ and the sociodemographic questionnaire in a waiting room and returned them to the research team without any identification. A clinical oral examination of the clean and dry teeth was performed by two examiners in a dental unit with the aid of a dental unit light. The parents were invited to answer a questionnaire on their socioeconomic background, measured in terms of the Brazilian minimum wage - BMW, a standard for this type of assessment, which corresponds to approximately US\$273.17 a month at the time of data collection [13].

The intraoral examination was performed on each patient using a plane mouth mirror, (Duflex, S.S. White LTDA, Rio de Janeiro, Brazil) and a CPI probe (Duflex, S.S. White LTDA, Rio de Janeiro, Brazil), according to the World Health Organization (WHO) recommendations for oral epidemiological surveys[14]. DMFT/dmft index was evaluated (decay, $\mathrm{m} / \mathrm{M}=$ missing, $\mathrm{f} / \mathrm{F}=$ filling, $\mathrm{t} /$ $\mathrm{T}=$ teeth, $\mathrm{d} / \mathrm{D}=\mathrm{dmft} / \mathrm{DMFT})$. The $\mathrm{D}$ component includes all teeth with caries (code 1) or filled, with caries (code 2). The M component comprises teeth (code 4), i.e., missing due to caries or for any other reason. The $\mathrm{F}$ component includes teeth only with code 3. The basis for DMFT calculations is 32 teeth, i.e., all permanent teeth including wisdom teeth. In the case of primary teeth, the calculation of the dmft index was similar, i.e., by deriving information from data codes A (sound crown), B (carious crown), C (filled crown, with caries), D (filled crown, with no caries), and $\mathrm{E}$ (missing tooth, due to caries) in the oral health assessment form.

\section{Outcome and explanatory variables}

The outcome variable was the impact on OHRQoL obtained with the PCPQ. The PCPQ has 31 items distributed into four subscales: oral symptoms (OS), functional limitations (FL), emotional well-being (EWB), and social well-being (SWB). The questions refer only to the frequency of events in the previous 3 months. The items are scored on a 5-point Liker scale as follows: never $=0$, once or twice $=1$, sometimes $=2$, often $=3$, and every day or almost every day $=4$. A “don't know" response was also permitted and was scored as 0 [11].

The main explanatory variable in our study was dental caries experience. To classify the patients based on caries experience, the patients underwent a dental examination in 
accordance with dmft/DMFT. The subjects were categorized based on their caries experience as: caries-free when $\mathrm{dmft} / \mathrm{DMFT}=$ 0 and caries experience when $\mathrm{dmft} / \mathrm{DMFT} \geq$ 1 [15]. Other explanatory variables collected included sex, patient's age, household income (classified based on Brazilian minimum wage, which was equal to US\$273.17 $-<1$ BMW; and $\geq 1$ BMW) [13], and maternal schooling ( $\leq 8$ years, $>8$ years) [13].

\section{Statistical analysis}

The Statistical Package for the Social Sciences (SPSS for Windows, version 20.0, SPSS Inc., Armonk, NY, USA) was used to analyze the data. Initially, descriptive analyses were made. The relative frequency (\%) of all the variables studied was obtained for characterization of the sample and of the components of the PCPQ. Multivariate Poisson regression with robust variance was performed to observe the association between overall PCPQ and subscales (outcome) with each independent variable [11]. All variables were included in the model. The age, caries experience, and maternal schooling were considered in the final model for all PCPQ subscales. The prevalence ratio (PR) and respective $95 \%$ confidence intervals were estimated for the variables that remained in the final model, and the level of significance was set at $5 \%$. Internal consistency was assessed by computing Cronbach's alpha for the questionnaire and for the subscales.

\section{RESULTS}

A total of 70 pairs of subjects and their parents or caregivers participated in the study. Most of the questionnaires were answered by mothers (93.3\%). The age of patients ranged from 2 to 14 years (median $=8, S D=3.76$ ). The study group consisted of $57(76.0 \%)$ males and $18(24.0 \%)$ females. Fifty (66.1\%) parents had more than eight years of education and
$35(46.7 \%)$ earned less than 2 BWM. Forty (53.3\%) subjects had no caries experience and $16(21.3 \%)$ had caries in deciduous dentitions. In the permanent dentitions, $36(48 \%)$ had no caries experience, whereas $16(21.3 \%)$ had caries experience (Table 1). The following means were obtained for caries experience: $\mathrm{dmft}=0.95( \pm 1.79)$ and DMFT $=1.02( \pm$ 1.93).

Table 1- Sample characterization and clinical data

\begin{tabular}{|ccc|}
\hline Variable & N & $\%$ \\
\hline Sex & 70 & 100 \\
\hline Male & 57 & 76.0 \\
\hline Female & 18 & 24.0 \\
\hline Years of schooling & $65^{\star}$ & 86.7 \\
\hline $\mathbf{8 8}$ & 15 & 20.0 \\
\hline "8 & 50 & 66.1 \\
\hline Household income & $65^{\star}$ & 86.7 \\
\hline «2 & 35 & 46.7 \\
\hline$\geq 2$ & 30 & 40.0 \\
\hline Age & 70 & 100 \\
\hline $\mathbf{5}$ & 31 & 44.3 \\
\hline 》 & 39 & 55.7 \\
\hline Caries experience dmft & $56^{\star}$ & 74.7 \\
\hline Caries-free & 40 & 53.3 \\
\hline Caries experience & 16 & 21.3 \\
\hline Caries experience DMFT & $52^{\star}$ & 69.3 \\
\hline Caries-free & 36 & 48.0 \\
\hline Caries experience & 16 & 21.3 \\
\hline
\end{tabular}

*OMissing

Table 2 presents the mean and standard deviation (SD) of the overall PCPQ and OS, FL, EWB and SWB subscale scores according to independent variables. The impact values were significantly higher than those found for sex in OS ( $\mathrm{p}<0.05$; Kruskal-Wallis and Mann Whitney tests). Individuals without caries in the permanent dentition had higher OHRQoL in SWB $(\mathrm{p}<0.05)$. 
Table 2 - Mean (SD) and subscale scores according to independent variables ( $N=70)$

\begin{tabular}{|c|c|c|c|c|c|}
\hline Variable & Overall PCPQ & $\begin{array}{c}\text { Oral } \\
\text { Symptoms }\end{array}$ & $\begin{array}{l}\text { Functional } \\
\text { limitations }\end{array}$ & Emotional Well-being & $\begin{array}{c}\text { Social } \\
\text { Well-being }\end{array}$ \\
\hline & Mean(SD) & Mean(SD) & Mean(SD) & Mean(SD) & Mean(SD) \\
\hline \multicolumn{6}{|c|}{ Sex } \\
\hline Male & $31.89(19.96)$ & $7.50(3.77)^{\mathrm{a}}$ & $11.17(7.86)$ & $6.22(5.74)$ & $7(7.20)$ \\
\hline Female & $25.86(22.50)$ & $6.43(4.50)^{b}$ & $9.14(5.90)$ & $4.57(7.82)$ & $5.71(8.97)$ \\
\hline \multicolumn{6}{|c|}{ PARENTS' YEARS OF SCHOOLING } \\
\hline$\leq 8$ years & $26.00(25.85)$ & $6.50(3.00)$ & $6.75(7.41)$ & $5.25(7.93)$ & $7.50(11.21)$ \\
\hline$>8$ years & $31.00(19.88)$ & $7.33(4.12)$ & 11.33(7.23) & $5.86(6.13)$ & $6.48(7.04)$ \\
\hline \multicolumn{6}{|c|}{ Household income } \\
\hline$<2$ BMW & $29.67(20.99)$ & $6.73(2.84)$ & $9.47(8.26)$ & $6.33(6.13)$ & $7.13(7.70)$ \\
\hline$\geq 2$ BMW & $31.00(20.59)$ & $7.90(5.25)$ & $12.30(5.55)$ & $4.90(6.69)$ & $5.90(7.69)$ \\
\hline \multicolumn{6}{|c|}{ GE } \\
\hline$\leq 6$ years & $26.50(19.06)$ & $3.93(3.27)$ & $7.83(5.70)$ & $5.50(7.25)$ & $9.23(10.03)$ \\
\hline$>7$ years & $32.58(24.53)$ & $7.73(4.41)$ & $10.39(8.19)$ & $6.76(7.33)$ & $7.70(8.59)$ \\
\hline \multicolumn{6}{|c|}{ CARIES EXPERIENCE dmft } \\
\hline Caries free & $28.41(19.83)$ & $7.06(4.46)$ & $11.06(7.61)$ & $5.29(6.40)$ & $5.00(5.85)$ \\
\hline Caries experience & $34(22.47)$ & $7.50(2.67)$ & $9.63(7.00)$ & $6.75(6.27)$ & $10.13(9.87)$ \\
\hline \multicolumn{6}{|c|}{ CARIES EXPERIENCEDMFT } \\
\hline Caries free & 32.67(20.15) & $7.61(2.63)$ & $10.72(7.82)$ & $6.33(5.94)$ & $8.00(8.23)^{a}$ \\
\hline Caries experience & 23.86 (21.22) & $6.14(6.33)$ & $10.29(6.34)$ & $4.29(7.31)$ & $3.14(4.14)^{b}$ \\
\hline
\end{tabular}

Values in columns with different superscript letters = statistically significant differences at $p<0.05$; Kruskal-Wallis test and MannWhitney test.

The results of the multivariate Poisson regression model for the impact of independent variables on the family's quality of life are shown in Table 3. Sex, caregivers schooling, age, and experience of caries remained non-significantly associated with parental perception of QoL. Household income $(\geq 2$ BMW) showed an association with OS. The overall Cronbach's alpha was 0.91 for the total questionnaire, suggesting good reliability. 
Table 3 - Multivariate Poisson regression model for association between independent variables ( $p \ll 0.05)$ and the overall B-FIS and specific subscales

\begin{tabular}{|c|c|c|c|c|c|c|c|c|c|c|}
\hline \multirow[t]{2}{*}{ Variables } & \multicolumn{2}{|c|}{ Overall PCPQ } & \multicolumn{2}{|c|}{ OralSymptoms } & \multicolumn{2}{|c|}{ Functional limitations } & \multicolumn{2}{|c|}{ Emotional Well-being } & \multicolumn{2}{|c|}{ Social Well-being } \\
\hline & $\operatorname{PR}(95 \% \mathrm{Cl})$ & p-value & $\operatorname{PR}(95 \% \mathrm{Cl})$ & p-value & $\operatorname{PR}(95 \% \mathrm{Cl})$ & p-value & PR(95\%Cl) & p-value & $\operatorname{PR}(95 \% \mathrm{Cl})$ & p-value \\
\hline \multicolumn{11}{|c|}{ Sex } \\
\hline Male & 1 & & 1 & & 1 & & 1 & & 1 & \\
\hline Female & $\begin{array}{c}1.20 \\
(0.62-2.31)\end{array}$ & 0.574 & $\begin{array}{c}1.14 \\
(0.71-1.81)\end{array}$ & 0.578 & $\begin{array}{c}1.12 \\
(0.67-1.89)\end{array}$ & 0.648 & $\begin{array}{c}1.11 \\
(0.31-3.98)\end{array}$ & 0.863 & $\begin{array}{c}1.23 \\
(0.37-3.37)\end{array}$ & 0.836 \\
\hline \multicolumn{11}{|c|}{ Years of schooling } \\
\hline$>8$ years & 1 & & 1 & & 1 & & 1 & & 1 & \\
\hline$\leq 8$ years & $\begin{array}{c}0.87 \\
(0.35-2.19)\end{array}$ & 0.782 & $\begin{array}{c}0.87 \\
(0.57-1.31)\end{array}$ & 0.516 & $\begin{array}{c}0.66 \\
(0.26-1.68)\end{array}$ & 0.390 & $\begin{array}{c}0.52 \\
(0.13-2.01)\end{array}$ & 0.350 & $\begin{array}{c}0.72 \\
(0.20-2.49)\end{array}$ & 0.606 \\
\hline \multicolumn{11}{|c|}{ Household income } \\
\hline$<2$ BMW & 1 & & 1 & & 1 & & 1 & & 1 & \\
\hline$\geq 2 \mathrm{BMW}$ & $\begin{array}{c}0.78 \\
(0.49-1.35)\end{array}$ & 0.391 & $\begin{array}{c}0.74 \\
(0.56-0.98)\end{array}$ & 0.036 & $\begin{array}{c}0.67 \\
(0.37-1.20)\end{array}$ & 0.183 & $\begin{array}{c}1.35 \\
(0.58-3.15)\end{array}$ & 0.480 & $\begin{array}{c}0.98 \\
(0.42-2.31)\end{array}$ & 0.979 \\
\hline \multicolumn{11}{|c|}{ GE } \\
\hline$>7$ years & 1 & & 1 & & 1 & & 1 & & 1 & \\
\hline$\leq$ 6years & $\begin{array}{c}0.83 \\
(0.47-1.46)\end{array}$ & 0.528 & $\begin{array}{c}0.63 \\
(0.63-1.42)\end{array}$ & 0.275 & $\begin{array}{c}1.22 \\
(0.78-1.90)\end{array}$ & 0.382 & $\begin{array}{c}0.79 \\
(0.25-2.44)\end{array}$ & 0.687 & $\begin{array}{c}0.67 \\
(0.34-3.37)\end{array}$ & 0.282 \\
\hline \multicolumn{11}{|c|}{ CARIES EXPERIENCE dmft } \\
\hline $\begin{array}{l}\text { Caries } \\
\text { experience }\end{array}$ & 1 & & 1 & & 1 & & 1 & & 1 & \\
\hline Caries free & $\begin{array}{c}0.91 \\
(0.54-1.51)\end{array}$ & 0.720 & $\begin{array}{c}0.96 \\
(0.74-1.26)\end{array}$ & 0.818 & $\begin{array}{c}1.16 \\
(0.68-1.97)\end{array}$ & 0.568 & $\begin{array}{c}0.76 \\
(0.33-1.75)\end{array}$ & 0.526 & $\begin{array}{c}0.53 \\
(0.21-1.32)\end{array}$ & 0.179 \\
\hline \multicolumn{11}{|c|}{ CARIES EXPERIENCEDMFT } \\
\hline $\begin{array}{l}\text { Caries } \\
\text { experience }\end{array}$ & 1 & & 1 & & 1 & & 1 & & 1 & \\
\hline Caries free & $\begin{array}{c}1.46 \\
(0.66-3.25)\end{array}$ & 0.346 & $\begin{array}{c}1.33 \\
(0.71-2.49)\end{array}$ & 0.360 & $\begin{array}{c}1.51 \\
(0.79-2.88)\end{array}$ & 0.209 & $\begin{array}{c}1.10 \\
(0.26-4.65)\end{array}$ & 0.892 & $\begin{array}{c}1.76 \\
(0.52-5.97)\end{array}$ & 0.362 \\
\hline
\end{tabular}

Note: $\mathrm{PR}=$ prevalence ratio; $\mathrm{Cl}=$ confidence interval.

\section{DISCUSSION}

Research into parental perceptions of OHRQoL is scarce in children with ASD. This cross-sectional study was the first to identify oral problems and to assess parental perception of OHRQoL of children with ASD in Brazil using the PCPQ. To the best of our knowledge, there are no published studies describing OHRQoL of children with autism in Brazil.

In relation to sex, the male to female ratio was $3: 1$; this might reflect the higher prevalence of autism in males, which concurs with the findings of the previously reported literature [4,5]. More biased prevalence in males could be the effect of the high level of fetal testosterone and potential genetic/ chromosomal effects [16]. Parents reported more oral health-related problems in male autistic patients. The higher prevalence of male subjects in our research may have influenced our results, with a higher impact on those in the OS subscale. These results are in agreement with Pani et al. [4] and Richa et al. [5].

The association between caries experience and parental perception of OHRQoL 
has been reported in the literature $[4,5,7,8,17$ $24]$. The impact observed in the present study was high, but higher impact was on caries-free children in the SWB domain. These findings differ from those of another study [5]. In the other study, significant correlation was found between DMFT and oral symptoms in children with autism [5]. On the other hand, caries experience means were higher than those of our study. The difference can be due to lower prevalence of caries in the sample associated with the analysis of caries experience, based on the WHO index. The index does not represent only an untreated lesion. Individuals with special needs with dental (experience untreated caries) are more likely to suffer high negative impact on their OHRQoL than those without dental caries experience [24]. Parents reported more problems in the OHRQoL of their children when the untreated lesion was considered [24] or in the case of severe caries [22]. In addition, many other factors have been attributed to the impact on autistic patients, such as caregivers' perception, family stress, severity of the disorders, household income, perceptions of child's autonomy level, educational level, and familial organization [4,7-9]. Our results show that other factors may have contributed to the greater impact on these children, regardless of their oral status. In an earlier study, with patients with special needs, a higher impact score was observed in older patients and when the severity of the caries was considered [22]. In this study sample, more impact was observed on patients $>7$ years old, but without statistical significance. Although parents reported more impacts on older individuals with special needs [24], these data should be seen with caution. It is important to be aware of the predictive limitations of cross-sectional studies: because the exposure and outcome are simultaneously assessed, there is generally no evidence of a temporal relationship between exposure and outcomes. Without longitudinal data, it is not possible to establish a true cause and effect relationship.

The PCPQ is divided into four domains designed to evaluate the exact parts of the child's oral well-being that affect the OHRQoL [12]. The oral symptoms and social wellbeing domains were statistically significant in relation to sex (male) and caries experience in the social well-being domain. This can perhaps be attributed to the fact that, while parents may be inclined to feel more sympathetic toward the disability of the child. It was interesting to note that, although the overall scores showed no significant diferences, the effects of autism on parental social well-being have been a cause for concern $[4,5]$. This maybe a reflection of the fact that older children, perceive caries as a problem that affects their social well-being $[4,5,23]$.

In this paper, PCPQ was used for this group of patients to understand parental perceptions. The PCPQ was used by Pani et al. [4] and Richa et al. [5]. In those studies, the means for total score and domain were higher in the dental caries experience group and in autistic children. The factors most frequently associated with the impact in quality of life was total household income and maternal age [4], and also oral symptoms, functional limitations, and emotional well-being [5]. In our study, household income had a positive influence on the OS domain. Parents with lower incomes experience more difficulties and those who considered their income insufficient to respond to their children's needs had a poorer quality of life. Pani et al. [4] did not find any association between total monthly household income and higher impact in quality of life. The study by Richa et al. [5] carried out with Indian ASD children reported similar results.

The oral health concerns of parents 
of autistic children may be masked by the children's various other medical and behavioral problems. In this regard, the finding of increased parental concern about the OHRQoL of autistic children seems to suggest that the use of OHRQoL scales as a tool to assess parental attitudes should be further investigated.

Many factors are important in assessing quality of life. Some of these factors include the classification of ASD, the severity of the disorder, and other associated signs and symptoms. Classification of ASD is one of the limitations of this research because of the reliance on reports of those responsible for the diagnosis of autism, the category and assessment of severity were not captured with the desired degree of accuracy. We would find it difficult to obtain a larger sample size. Future studies on this group of patients could include detailed medical records in order to better understand the effects of OHRQoL on autistic children, giving preventive support to monitor and improve oral health and the general well-being of this group of patients.

\section{CONCLUSION}

Children with ASD had a high impact score in OS, regardless of the caries experience presence. The evaluation of OHRQoL can help health care providers in planning and decisionmaking process regarding the implementation of prevention and control measures at oral health services. It is important to promote and to encourage the search for preventive dental care in autism.

\section{COMPLIANCE WITH ETHICAL STANDARDS}

Funding: This study was not funded.

Conflict of Interest: All authors declare that they have no conflict of interest.
Ethical approval: All procedures performed in studies involving human participants were in accordance with the ethical standards of the institutional and/or national research committee and with the 1964 Helsinki declaration and its later amendments or comparable ethical standards. This study was approved by the Human Research Ethics Committee of Fluminense Federal University (439.086/2013).

Informed consent: Informed consent was obtained from all individual participants included in the study.

\section{REFERENCES}

1. American Academy of Pediatric Dentistry. Guideline on Management of Dental Patients with Special Health Care Needs. 2008-2012; 37:6, 166-171.

2. Faker K, Di Lanaro N, Paula VAC, Tostes MA. Profile of special needs patients assisted in a dental project. BrazDent Sci. 2016;19:4,14-20. doi:10.14295/ bds.2016.v19i4.1300

3. Instituto Brasileiro de Geografia e Estatística. Canso demográfico 2010 [internet]. [cited 2019 ago]. Available from: https://www.eatright.org/.http:// www.ibge.gov.br/home/estatistica/populacao/cens02010/default.shtm.

4. Pani SC, Mubaraki SA, Ahmed YT, Alturki RY, Almahfouz SF.Parental perceptions of the oral health related quality of life of autistic children in Saudi Arabia. Spec Care Dentist. 2013 Jan-Feb;33(1):8-12. doi:10.1111/j.17544505.2012.00294.X.

5. Richa YR, Puranik MP.Oral health status and parental perception of child oral health related quality-of-life of children with autism in Bangalore. J Indian Soc Pedod Prev Dent. 2014 Apr-Jun;32(2):135-9. doi:10.4103/0970-4388.130967.

6. Abanto J, Carvalho TS, Bönecker M, Ortega A0, Ciamponi AL, Raggio DP. Parental reports of the oral health-related quality of life of children with cerebral palsy. BMC Oral Health. 2012 Jun 18;12:15. doi: 10.1186/1472-6831-12-15.

7. Weckwerth SA, Weckwerth GM, Ferrairo BM, Chicrala GM, Ambrosio AM, Toyoshima GH, et al. Parents' perception of dental caries in intellectually disabled children. Spec Care Dentist. 2016 Nov;36(6):300-306. doi: 10.1111/ scd.12191.

8. Aggarwal VP,Mathur A, Dileep CL, Batra M, Makkar DK. Impact of sociodemographic attributes and dental caries on quality of life of intellectual disabled children using ECOHIS. Int J Health Sci (Qassim). 2016;10;4:480-90.

9. Alves NS, Gavina VP,Cortellazzi KL, Antunes LA, Silveira FM, Assaf AV. Analysis of clinical, demographic, socioeconomic, and psychosocial determinants of quality of life of persons with intellectual disability: a cross-sectional study. Spec Care Dentist. 2016 Nov;36(6):307-314. doi: 10.1111/scd.12196.

10. Fernandes ML, Kawachil,Corrêa-Faria P,Paiva SM,Pordeus IA. The impact of the oral condition of children with sickle cell disease on family quality of life. Braz Oral Res. 2016;30. pii:S1806-83242016000100221. doi: 101590/18073107BOR-2016.vol30.0021. 
11. Jokovic A, Locker D, Stephens M, Kenny D, Tompson B, Guyatt G. Measuring parental perceptions of child oral health-related quality of life. Journal of Public Health Dentistry. 2003;63;2:67-72.

12. Goursand D, Ferreira MC, Pordeus IA. Mingoti SA, Veiga RT, Paiva SM. Development of a short form of the Brazilian Parental-CaregiverPerceptions Questionnaire using exploratory and confirmatoryfactor analysis. Qual Life Res. 2013 Mar;22(2):393-402. doi: 10.1007/s11136-012-0145-3.

13. Corrêa-Faria P,Paiva SM,Pordeus IA. Ramos-Jorge ML. Influence of clinical and socioeconomic indicators on dental trauma in preschool children. Braz Oral Res. 2015;29:1-7.

14. World Health Organization. Oral health surveys, basics methods. 5th ed. Geneva: Word Health Organization. 2013.

15. Chaffee BW, RodriguesPH, Kramer PF.Vítolo MR, Feldens CA. Oral healthrelated quality-of-life score differ by socioeconomic status and caries experience. Community Dent Oral Epidemiol. 2017 Jun;45(3):216-224. do: 10.1111/cdoe.12279.

16. Baron-Cohen S, Lombardo MV, Auyeung B, Ashwin E, Chakrabarti B, Knickmeyer R. Why are autism spectrum conditions more prevalent in males? PLoS Biol. 2011 Jun;9(6):e1001081. doi: 10.1371/journal.pbio.1001081.

17. Ramos-Jorge J, Alencar BM, Pordeus IA, Soares ME, Marques LS, RamosJorge ML, Paiva SM. Impact of Dental caries on quality of life among preschool children: emphasis on the type of tooth and stages of progression. Eur J Oral Sci. 2015 Apr;123(2):88-95. doi: 10.1111/eos.12166.
18. Guedes RS, Ardenghi TM, Piovesan C. EmmanuelliB, Mendes FM. Influence of initial caries lesions on quality of life in preschool children: a 2-year cohort study. Community Dent Oral Epidemiol. 2016 Jun;44(3):292-300. doi:10.1111/ cdoe.12217.

19. Firmino RT, Gomes MC, Vieira-Andrade RG, Martins CC, Paiva SM, GranvilleGarcia AF.Case-control study examining the impact of oral health problems on the quality of life of the families of preschoolers. Braz Oral Res; $2016 \mathrm{Nov}$ 28;30(1):e121. doi:10.1590/1807-3107BOR-2016.vol30.0121.

20. Clementino MA, Gomes MC, Pinto-Sarmento TC,Martins CC, Granville-Garcia AF,Paiva SM. Perceived Impact of Dental Pain on the Quality of Life of Preschool Children and Their Families. PLoS One. 2015 Jun 19;10(6):e0130602. doi: 10.1371/journal.pone.0130602

21. Gomes MC, Clementino MA, Pinto-Sarmento TC, Costa EM, Martins CC, Granville-Garcia AF,Paiva. Parental Perceptions of Oral Health Status in Preschool Children and Associated Factors. Braz Dent J. 2015 JulAug;26(4):428-34. doi: 10.1590/0103-6440201300245.

22. Cancio V,Faker K, Bendo CB, Paiva SM, Tostes MA. Individuals with special needs and their families oral health-related quality of life. Braz Oral Res. 2018 May 24;32:e39. doi:10.1590/1807-3107bor-2018.vol32.0039.

23. Eslami N,Movahed T,Masoumeh A. Parents perceptions of the oral healthrelated quality of life of their autistic children in Iran. The Journal of Clinical Pediatric Dentistry.2018;42;6:-9. doi:10.17796/1053-4625-426.3

24. Faker K, Tostes MA, Cancio V. Impact of untreated dental caries on oral healthrelated quality of life of children with special health care needs. Braz Oral Res. 2019 Mar 18;32:e117. doi: 10.1590/1807-3107BOR-2018.vol32.0117.

\section{Dra Viviane Cancio}

(Corresponding address)

Universidade Federal Fluminense/Faculdade de Odontologia

Rua Mário Santos Braga, no 30 - Campus Valonguinho, Centro,

Niterói, RJ, Brazil, CEP 24040-110

Date submitted: 2019 Jun 25

E-mail: odonto.cancio@gmail.com 